\title{
Genetic variation in agamospermous microspecies of Taraxacum sect. Erythrosperma and sect. Obliqua
}

\author{
H. Van Oostrum, A. A. Sterk \\ and $H$. J. W. Wijsman
}

\author{
Hugo de Vries Laboratorium, Pl. Middenlaan 2a and \\ Institute of Genetics, Kruislaan 318; University of \\ Amsterdam, Amsterdam, The Netherlands
}

\begin{abstract}
Agamospermous microspecies of Taraxacum have been studied at the isozyme level. $T$. tortilobum and $T$. rubicundum (sect. Erythrosperma), both of a fairly broad ecological amplitude, consisted of several clones. In Holland only a few clones occur compared with the situation in Central Europe. By contrast, in $T$. obliquum (sect. Obliqua), restricted to the outer dune habitat, no genetic variation could be demonstrated at the Dutch sites sampled. As an explanation for genetic polymorphism in agamospermous taxa either inheritance from sexual ancestors or possible facultative agamospermy is discussed.
\end{abstract}

\section{INTRODUCTION}

Taraxacum in Europe is a polyploid complex consisting of sexual diploid and agamospermous polyploid taxa. There is no consensus as to the systematics of the group. Some authors use a microspecies concept and unite the microspecies into sections like sect.Taraxacum and sect.Erythrosperma (cf. Richards and Sell, 1976). Others use a macrospecies concept broadly coinciding with the sections mentioned ( $T$. officinale and $T$. levigatum, respectively, Hesz et al., 1972). From a population genetical point of view such macrospecies (or sections) are very heterogeneous units. Within $T$. officinale and $T$. levigatum in Europe there are sexual diploids and agamospermous triploids and tetraploids in addition to hundreds of morphs which are morphologically more or less recognisable. Many of these morphs are genetically controlled (Kappert, 1954; Nilsson, 1947). In one pasture in Holland the dandelion flora can consist of 20 or more microspecies of the section Taraxacum (Sterk et al., 1983), while in the dune habitat eight microspecies of section Erythrosperma can grow together (Nijs et al., 1978). For the study of the

Reprint requests to: $\operatorname{Dr}$ A. A. Sterk, Hugo de Vries Laboratorium, P1. Middenlaan 2a, 1018 DD Amsterdam, The Netherlands genetic structure of natural agamospermous triploid populations of Taraxacuum in relation to ecology and geography, the best starting point is to select a morphologically well recognisable microspecies with a wide ecological amplitude and to compare it with an equally distinct microspecies of a narrow amplitude.

The microspecies T. tortilobum Florstr. (sect. Erythrosperma) is found to be "generalist" (Sterk et al., 1983), of broad ecological amplitude in dry grasslands. The taxon has been recognised in the several revisions of the section (van Soest, 1957; Doll, 1973; Hagendijk et al., 1975). It is morphologically distinct, triploid $(2 n=24$, Nijs et al., 1978) and agamospermous, and occurs from the North Sea to Central Europe (Switzerland, North and Central France, and scattered over the South of France). It is a very young taxon when Doll's criteria are applied (Doll, 1982). As yet there is no evidence for resexualisation, facultative agamospermy or the occurrence of sexual, diploid populations. Some authors quoted in Nijs and Sterk (1980) and Doll (1972) found sexuality and facultative agamospermy in the section Erythrosperma in Central and Southern Europe.

In the present pilot study we wished to compare such an easily identified microspecies of a generalist character with a "specialist" taxon, that is, of a narrow ecological amplitude. We have chosen the microspecies T. obliquum (Fr.) Dahlst., the 
only representative of the section Obliqua in the Netherlands. In Sterk et al. (1983), T. tortilobum and T. obliquum are contrasted in their ecological difference. $T$. obliquum is triploid $(2 n=24$, Nijs et al., 1978) and agamospermous; no evidence for facultative agamospermy or sexuality has been produced. The microspecies occurs along the coasts of the Netherlands, Germany, S. Norway, Denmark and S. Sweden. Van Soest (1939) stressed that the species is very sensitive to human disturbance.

In the same coastal dunes as the two microspecies mentioned another species of the section Erythrosperma could be investigated, $T$. rubicundum (Dahlst.) Dahlst., a "generalist" in the terminology of Sterk et al. (1983). For this species, Doll (1972) has stressed its intra-microspecific variability, partly to be ascribed to its sexuality and its facultative agamospermous character in the south of its wide area of distribution (from $\mathrm{S}$. Sweden through W. and Central Europe to the northwestern Mediterranean zone). From the Netherlands only triploid plants are known.

The present study has collected isozyme data of several mainly Dutch populations of the microspecies so as to study their clonal composition. The three microspecies have a very specific habit and do not resemble the average dandelion of section Taraxacum.

\section{MATERIAL AND METHODS}

\section{(i) Plant material}

Several sites in the Netherlands were sampled. In inland localities T.tortilobum is either found at protected dry grassland sites, which limits the number legally removed, or unauthentically on roadsides where (dune) sand has been applied. By contrast, in the dune area T.tortilobum ( $T$ ) and T. rubicundum ( $\mathrm{R}$ ) are common; T. obliquum $(\mathrm{O})$ is less common and populations are small. Sites sampled were the following (numbers refer to the map, fig. 1): 1 . Texel, four populations: $24+10+$ $29 \mathrm{~T}, 26 \mathrm{O} ; 2$. North Holland Dune Reserve, seven populations: $10+25+20+5+31 \mathrm{~T}, 38 \mathrm{O}, 16 \mathrm{R}$; 3. Ommen, $18 \mathrm{~T}$ : 4 . Vreugderijker waard near Zwolle, $7 \mathrm{~T} ; 5$. Gooi, 4 populations: $15+18+16+7$ $\mathrm{T}$ (5a and 5c) along a bicycle track); 6 . Poederooyen, $7 \mathrm{~T}$; 7. Koekkoekswaard near Ameide, 25 T; 8 Oeffelte, $17 \mathrm{~T}$; 9 . Donderberg near Swalmen, Limburg, $16 \mathrm{~T} ; 10$. Sivry sur Meuse, France (55), $20 \mathrm{~T} ; 11$. Brissheim (SW of Freiburg, FRG) $14 \mathrm{~T}$.

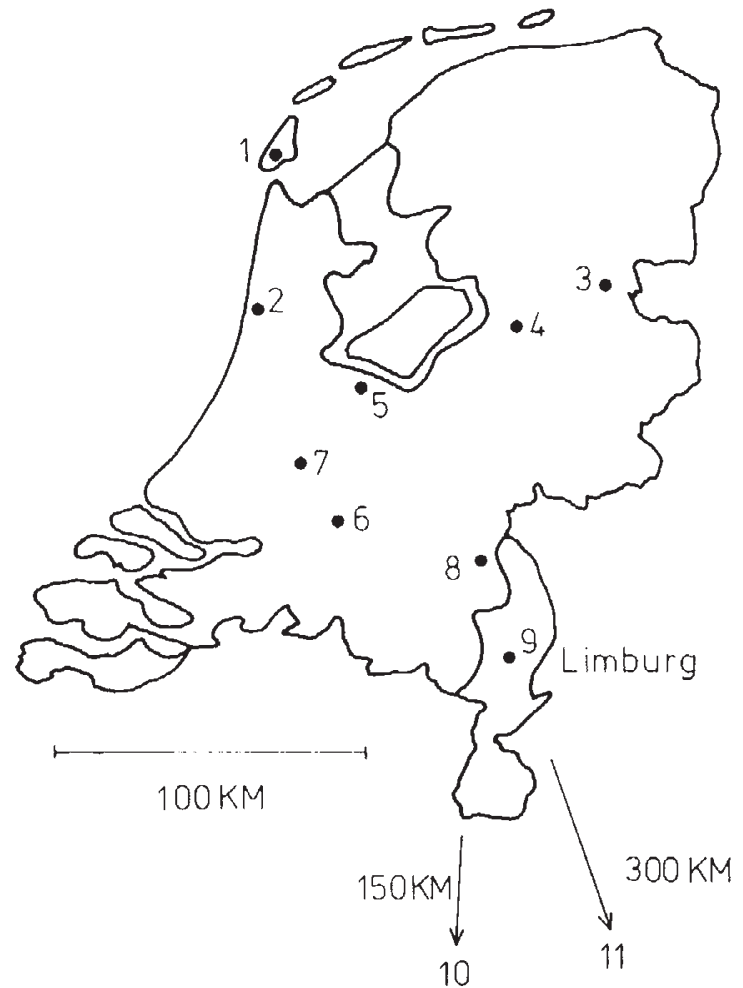

Figure 1 Map of the Netherlands with the locations of the populations studied.

\section{(ii) Electrophoresis}

Leaf extracts were typed for their allozyme pattern by assaying the enzymes peroxidase (PRX), malate dehydrogenase (MDH), esterase (EST), NADH dehydrogenase (NDH), acid phosphatase (ACP), malic enzyme (ME), superoxide dismutase (SOD). Starch gel electrophoresis was used in combination with two buffer systems. The citrate system consists of 14 per cent starch gels with electrode buffer $0.67 \mathrm{M}$ Trishydroxy aminomethane(Tris, $0.2 \mathrm{M}$ citrate, $0.03 \mathrm{M} \mathrm{NaCl}, p \mathrm{H} 6.2$; gel buffer $1 / 10$ of electrode buffer. The borate system consists of 12 per cent starch gels with electrode buffer $0.125 \mathrm{M}$ Tris, $0.163 \mathrm{M}$ borate, $0.004 \mathrm{M} \mathrm{Na2-EDTA}, p \mathrm{H} 8.0$, gel buffer identical but for $0.121 \mathrm{M}$ borate and $p \mathrm{H}$ $8 \cdot 2$. Me and SOD could not be stained well in citrate buffer and only for these was the borate system used. It proved to be essential that the leaves were freshly collected during wintertime, briefly frozen and homogenated on ice in $0.1 \mathrm{ml}$ extraction fluid $(0.14 \mathrm{M} \mathrm{NaCl}+0.02 \mathrm{M} \mathrm{NaNO} 3)+$ $50 \mathrm{mg}$ Dowex-1(Sigma). The Dowex concentration prevents smears of stain but influences the migrational distance of individual bands. The extract was adsorbed onto paper wicks through thin filter 
paper. Gels were run at $50 \mathrm{~mA}$ for $3 \mathrm{~h}$ (until the front had reached $5 \mathrm{~cm}$ ), stained, and fixed in 50 per cent methanol. For the staining assays the following recipes were used: $\mathrm{MDH}, \mathrm{ME}, \mathrm{ACP}$ : Siciliano and Shaw (1976); PRX: Shaw and Prasad (1970); EST: slightly modified from Shaw and Prasad (1970) as follows: $0.03 \mathrm{mg}$ of $\alpha$ and $\beta$-naphthyl acetate each and $100 \mathrm{mg}$ Fast Blue RR were dissolved separately in some drops of dimethyl sulfoxide, then mixed and added to phosphate buffer $(0 \cdot 1 \mathrm{M}, p \mathrm{H} 7 \cdot 0)$, after which the solution was filtered; staining took place overnight; NDH: according to Mastenbroek et al. (1981). SOD could be scored as white bands in the ME assay.

\section{RESULTS}

\section{(i) Isozymes}

Isozyme patterns have been scored for most plants with respect to ACP, NDH, PRX, EST, MDH, SOD, ME. Some other enzyme stains gave no results in our combination of gel and buffers. For SOD and ME the phenotypes were invariant. However, for ACP, NDH, PRX, EST and MDH variation was seen in $T$. tortilobum and for ACP, NDH, and PRX in T. rubicundum. T. obliquum (64 plants) was completely uniform.

For the interpretation of isozyme data, comparisons should be made with sexual relatives. Vinkenoog and Wijsman (preliminary data) scored mendelian inheritance of certain enzyme bands in diploid progeny of sexual Taraxacum (of the section Taraxacum). The impression is formed that the case of ACP in addition to slow and fast bands homodimeric bands are observed. For NDH it seems reasonable to assume that the only dark zone represents products of one locus; double or triple heterozygotes are found. In the case of PRX, EST, and $\mathrm{MDH}$ absence or presence of, respectively, PRX-7, EST-5, and MDH-5 is involved (cf. fig. 2); the latter three situations each won't involve more than one locus. The several combinations of isozymes are listed in table 1.

\section{(ii) Genotypes}

Since the five cases of variation each represent one locus, the phenotypes can be rendered as genotypes. The polymorphism as found involves 15 genotypes for T. tortilobum and five genotypes for T. rubicundum. In table 2 the distribution of the genotypes over the populations is given.

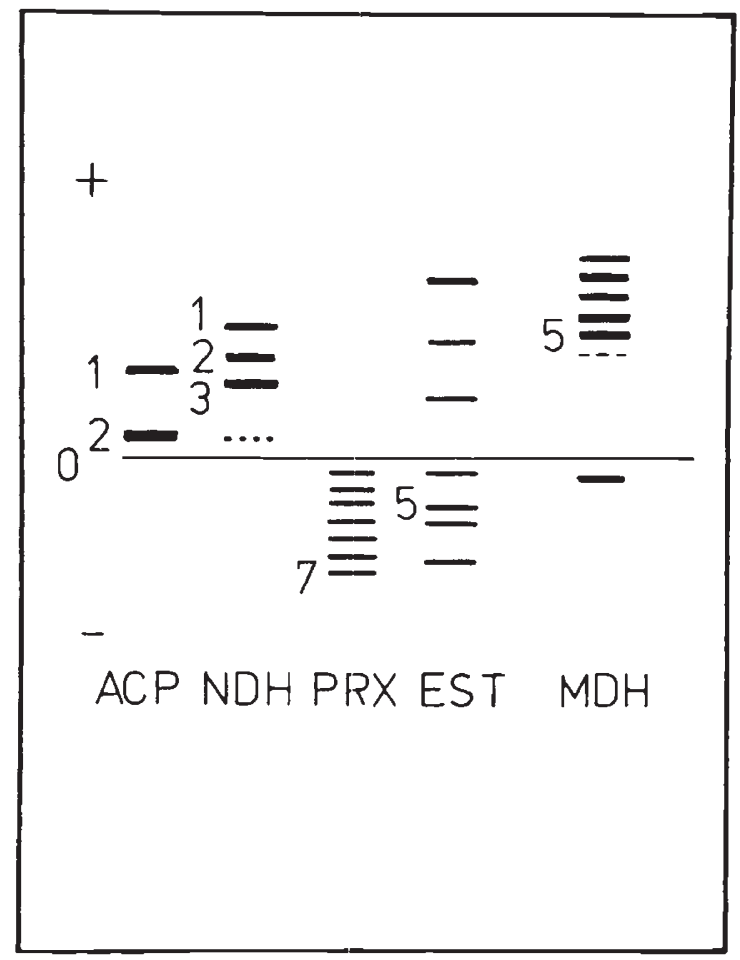

Figure 2 Isozyme bands in Taraxacum as found in the species studied. The bands have been numbered from + to - . Broken lines stand for weak bands. The rf values can be found in table 2. Note that ACP is a dimeric enzyme, making a homodimeric band appearing between 1 and 2 in the heterozygote.

It must be stressed that only the minimum number of clones has been determined. Using additional enzyme systems might reveal additional variation. The impression is formed that the variability over most of the Netherlands is lower than that in the extreme south-east of the country and from there southward.

The only genotype found in T. obliquum coincided with the $P$ genotype of table 1 , but this must be considered fortuitous and not indicative of a special relationship to T. rubicundum.

\section{DISCUSSION}

We have demonstrated that the local flora of triploid agamospermous microspecies of Taraxacum can consist of a number of genotypes.

The presence of many clones, that is, at least of many microspecies in one field has been firmly established (cf. Sterk et al., 1983). In the USA, Solbrig (1970) and Solbrig and Simpson (1974; 
Table 1 Phenotypes in the Taraxacum species studied for variable loci. In these asexual types each phenotype corresponds to a clone. The position of the relevant bands on the gel is indicated in fig. 2. $\mathrm{rf}=$ migrational distance of a particular band with reference to the buffer front

\begin{tabular}{|c|c|c|c|c|c|c|c|c|}
\hline enzyme & $\mathrm{ACP}$ & & $\mathrm{NDH}$ & & & PRX & EST & $\mathrm{MDH}$ \\
\hline band number & 1 & 2 & 1 & 2 & 3 & 7 & & 5 \\
\hline rf & 0.40 & $0 \cdot 10$ & 0.48 & 0.42 & $0 \cdot 36$ & $0 \cdot 40$ & 0.24 & 0.44 \\
\hline
\end{tabular}

\begin{tabular}{|c|c|c|c|c|c|c|c|c|}
\hline \multicolumn{9}{|c|}{$\begin{array}{l}\text { clones } \\
T \text {. tortilobum }\end{array}$} \\
\hline A & + & $t$ & - & + & - & - & + & + \\
\hline B & + & + & - & + & + & - & + & + \\
\hline C & - & + & - & + & - & - & + & + \\
\hline D & - & + & - & + & + & - & + & + \\
\hline $\mathrm{E}$ & + & + & - & + & + & - & - & + \\
\hline$F$ & - & + & & + & + & - & - & + \\
\hline G & - & + & - & + & - & - & - & + \\
\hline $\mathrm{H}$ & + & $t$ & - & + & + & + & - & $t$ \\
\hline I & $t$ & - & - & + & + & - & + & - \\
\hline $\mathrm{J}$ & + & + & + & + & + & - & + & - \\
\hline K & + & - & + & + & + & - & + & $\ldots$ \\
\hline $\mathrm{L}$ & + & + & - & + & + & - & + & - \\
\hline $\mathrm{M}$ & + & + & - & - & + & - & + & + \\
\hline $\mathrm{N}$ & + & + & + & + & + & - & + & + \\
\hline $\mathrm{O}$ & - & + & - & t & - & - & + & + \\
\hline \multicolumn{9}{|c|}{ T. rubicundum } \\
\hline $\mathbf{P}$ & + & + & - & + & - & - & + & - \\
\hline Q & + & + & - & + & + & + & + & -- \\
\hline $\mathrm{R}$ & + & - & - & + & + & + & + & - \\
\hline S & + & + & - & + & - & + & + & - \\
\hline$T$ & + & - & - & + & - & - & + & - \\
\hline
\end{tabular}

Table 2 Incidence of the clonal types of table 1 in the populations sampled of $T$. tortilobum. The populations are numbered according to the map, fig. 1. Letters in small case refer to sub-populations

\begin{tabular}{|c|c|c|c|c|c|c|c|c|c|c|c|c|c|c|c|c|}
\hline \multicolumn{7}{|c|}{ population } & \multicolumn{10}{|c|}{ clones } \\
\hline & & A & B & C. & D & $\mathrm{E}$ & $F$ & $G$ & $\mathrm{H}$ & I & $\mathbf{J}$ & $\mathrm{K}$ & $\mathrm{L}$ & $\mathbf{M}$ & $N$ & $\mathrm{O}$ \\
\hline \multirow[t]{3}{*}{1} & $a$ & 3 & 19 & & 2 & & & & & & & & & & & \\
\hline & $b$ & 1 & 7 & & 2 & & & & & & & & & & & \\
\hline & $c$ & & 29 & & & & & & & & & & & & & \\
\hline \multirow[t]{5}{*}{2} & $a$ & 5 & 5 & & & & & & & & & & & & & \\
\hline & $b$ & 4 & 20 & 1 & & & & & & & & & & & & \\
\hline & $c$ & 6 & 14 & & & & & & & & & & & & & \\
\hline & $d$ & 1 & 2 & 1 & 1 & & & & & & & & & & & \\
\hline & $\mathcal{c}$ & 6 & 25 & & & & & & & & & & & & & \\
\hline 3 & & 18 & & & & & & & & & & & & & & \\
\hline 4 & & 6 & & 1 & & & & & & & & & & & & \\
\hline \multirow[t]{4}{*}{5} & $a$ & 3 & 12 & & & & & & & & & & & & & \\
\hline & $b$ & 6 & 11 & & 1 & & & & & & & & & & & \\
\hline & $c$ & 4 & 3 & & & 3 & 1 & 3 & 2 & & & & & & & \\
\hline & $d$ & 1 & 6 & & & & & & & & & & & & & \\
\hline 6 & & 2 & 3 & 1 & 1 & & & & & & & & & & & \\
\hline 7 & & 13 & 8 & 2 & 2 & & & & & & & & & & & \\
\hline 8 & & 6 & 11 & & & & & & & & & & & & & \\
\hline 9 & & 5 & 3 & 1 & 2 & 2 & 1 & 2 & & & & & & & & \\
\hline 10 & & 7 & 5 & 2 & & & & & & & & & 1 & 1 & 3 & 1 \\
\hline 11 & & 2 & 2 & & & & & & & 8 & 1 & 1 & & & & \\
\hline
\end{tabular}

1977) found several genotypes together. The study of Lyman and Ellstrand (1984), in which local clonal diversity was established in T. officinale (=sect. Taraxacum treated as one macrospecies), was therefore seeking the obvious. In our opinion, the microspecies concept can in certain cases actually be worked with and can apparently find application to genetic units subject to natural selection. The interesting point then is the presence of many clones in the populations of the microspecies T. tortilobum and T. rubicundum. It is tempting to postulate a correlation between this variability and the broad ecological amplitude of both microspecies. However, in the case of T.tortilobum North of the Dutch province of Limburg only four clones occur, of which two comprise 94 per cent. These data in themselves would not support the hypothesis that ecological tolerance in an asexual taxon would be dependent on the presence of many clones. It is possible, if not likely, that presence of more clones could be demonstrated if more gene loci are examined. (One apparent exception, the population Gooi-c, with much variation, was from sand along a bicycle track that may have been transported from elsewhere in the country).

We think the invariance of the isozyme pattern for $T$. obliquum is significant, because the number of plants investigated sufficed to allow detection of a minority if present. It would be interesting to extend population sampling to the more central parts of its area of distribution, the coasts of Denmark and the Baltic Sea to investigate whether possibly only one clone is occupying the whole geographic and (narrow) ecological range. After all, the splitter's limit would be describing clones as microspecies with only one genotype (Richards, 1970).

The degree of polymorphism in agamospermous species is anyhow considerably reduced because it is not determined by the diversity of alleles but by the diversity of full clones. In the samples from France and Germany, as well as those from Limburg, many clones have found in addition to the two majority types. It is predicted that in the more southern parts of its area T. tortilobum, like T. rubicundum (Doll, 1972), will sport more variation. This can be related to the theory that Taraxacum sect. Erythrosperma survived glacial periods in Southern Europe. This theory is supported by the fact that the relatively old diploid sexuals occur in the latter area. In post-glacial times the dandelions extended their area to the North and formed by large scale hybridisation polyploid (mostly triploid, and more seldom tetraploid) agamospermous populations. 
Going northward the environment becomes less diverse and more severe, and that could be the reason for a concomitant reduction of the variability by natural selection. In some animals a pattern of polyclonal parthenogenetic species ("races") in northern Europe and diploid polymorphic populations in central Europe has been found (Suomalainen et al., 1976) that closely resembles the present situation in Taraxacum (Doll, 1982; Nijs and Sterk, 1980).

If the variation in isozyme pattern had been very restricted, we might have been concerned with "sibling microspecies", that is, with a few clones of different evolutionary history with a superficially similar morphology. As it is, in the Netherlands 15 combinations of the four variable loci are represented in our sample. This looks more like polymorphism of a hybrid swarm being fixed by asexuality although the frequencies of the morphs may have changed afterwards by selection. The theory of the acquisition of sex-limited meiosis suppressors and autonomous embryony as the only way for expansion open to triploid hybrids Richards, 1973; Hebert and Crease, 1983) can be invoked to explain the latter fixation. The ancestral population complex was probably sufficiently specialised to have geographically differentiated morphological characters and was probably polymorphic, particularly if a range of habitats was occupied. In that case the present-day morphologically defined agamospermous microspecies would consist of a (restricted) number of genotypes. T. tortilobum is a very young taxon, which reduces the chances for mutation to be responsible for the variation observed, as it is the case in the very old asexual species without living sexual relatives, the snail Thiara balonnensis (Stoddart, 1983).

To what degree sexuality or spurious facultative agamospermy is involved in the variability patterns cannot be said. Evidence for the occurrence of haploid female gametes is lacking. Haploid pollen in the sections Taraxacum is occasionally formed in the south of the Netherlands and in more continental regions (den Nijs and co-workers, pers. comm.), but has not yet been demonstrated in sect. Erythrosperma. This can be explained by the fact that sect. Erythrosperma is more thermophilous than sect. Taraxacum. Sexual diploids of sect. Erythrosperma (which are more thermophilous than the agamospermous triploids) would not extend as far north as the sexual diploids of sect. Taraxacum. However this may be, some authors have stressed that certain meiotic aberrations would allow a restricted amount of genetic recombination even in strictly agamospermous clones of Taraxacum (Sørensen, 1958; Malecka, 1973).

At site 9 (Swalmen, Limburg), plants have been found combining characters of section Erythrosperma with those of sect. Taraxacum, and not identifiable at the microspecies level (Hagendijk and Zevenbergen, pers.comm.). However, all dandelions at the site will have to be studied in much more detail before hybridisation can be considered to occur and the remarkably high variability can be explained.

Acknowledgements We wish to thank E. Roetman, I. van den Boer, J. W. M. Pinckaers and J. C. M. den Nijs for their assistance in collecting the plants, as well as R. Vinkenoog for interpreting the formal genetics.

\section{REFERENCES}

DOLL, R. 1972. Die apomiktische Art und ihre Beziehung zur Evolution, in: Wiederspiegelung der Binnenstruktur und Dynamik der Art in der Botanik, Ed. W. Vent. Symp. Arbeitsgemeinsch. Phytotax. Biol. Gesell. DDR, 161-174.

DOLL, R. 1973. Revision der sect. Erythrosperma Dahlst. emend. Lindb. f. der Gattung Taraxacum Zinn. Feddes Repert., 84, 1-180.

DOLL, R. 1982. Grundriss der Evolution der Gattung Taraxacum Zinn. Feddes Repert., 93, 481-624.

HAGENDIJK, A., SOEST, J. L. VAN, AND ZEVENBERGEN, H. A. 1975. Taraxacum Wigg., in Flora Neerlandica IV, afl. 9. Koninklijke Nederlandse Botanische Vereniging, Amsterdam.

HERBERT, P. D. N. AND CREASE, T. 1983. Clonal diversity in populations of Daphnia pulex reproducing by obligate parthenogenesis. Heredity, 51, 353-369.

HESZ. H. E., LANDOLT, E. AND HIRZEL, R. 1972. Flora der Schweiz 3, 618-623, Birkhäuser Verlag, Basel.

KAPPERT, H. 1954. Experimentelle Untersuchungen über die Variabilität eines Totalapomicten. Ber. Deutsch. Bot. Ges., 67, 325-334.

LYMAN, J. C. AND ELLSTRAND, N. C. 1984. Clonal diversity in Taraxacum officinale (Compositae), an apomict. Heredity, 53, 1-10.

MASTENBROEK, O., BREDERODE, J. VAN, NIEMANN, G. J. AND NIGTEVECHT, G. VAN. 1981. Changes in isoenzyme patterns during the ontogeny of Silene alba (=S.pratensis). Bioch. Physiol. Pflanzen, 176, 584-589.

MALECKA, J. 1973. Problems of the mode of reproduction in microspecies of Taraxacum section Palustria Dt. Acta Biol. Cracov., 16, 37-84.

NIJS, J. C. M. DEN, STERK, A. A. AND HAMMEN, H. VAN DER. 1978. Cytological and ecological notes on the Taraxacum sections Erythrosperma and Obliqua of the coastal area of the Netherlands. Acta Bot. Neerl., 27, 287-305.

NIJS, J. C. M. IDEN AND STERK, A. A. 1980. Cytogeographical studies of Taraxacum sect. Taraxacum (=sect. Vulgaria) in Central Europe. Bot. Jahrb. Syst., 101, 527-554.

NILSSON, H. 1947. Totale inventierung der Mikrotypen eines Minimal Areals von Taraxacum officinale. Hereditas 33, 119-142.

RICHARDS, A. J. 1970. Eutriploid facultative agamospermy in Taraxacum. New Phytol., 69, 761-774. 
RICHARDS, A. J. 1973. The origin of Taraxacum agamospecies. Bot. J. Linn. Soc., 66, 189-211.

RICHARDS, A. J. AND SELL, P. D. 1976. Taraxacum Wigg. In: Flora Europaea 4, 332-343. C.U.P., Cambridge.

SHAW, C. R. ANI) PRASAD, R. 1970. Starch gel electrophoresis-a compilation of recipes. Bioch. Genet., 4, 297 320.

SICILIANO, M. J. AND SHAW, C. R. 1976. Separation and visualisation of enzymes on gels, in Chromatographic and electrophoretic techniques (ed. S. I. Smith). Heinemann, London, pp. 185-209.

SOEST, J. L. VAN. 1939. Het geslacht Taraxacum in Nederland. I. Ned. Kruidk. Arch., 49, 213-237.

SOEST, J. L. VAN. 1957. Taraxacum sectio Obliqua Dt. en sectio Erythrosperma Dt. em. Lb. in Nederland. Acta Bot. Neerl, 6, 74-92.

SOLBRIG. O. 1970. Genotypic variation within and between populations of the common dandelion, Taraxacum officinale Wigg. Isozyme Bulletin, 3, 43-44.
SOLBRIG, O. AND SIMPSON, B. B. 1974. Components of regulation of a population of dandelions in Michigan. $J$. Ecol., 62, 473-486.

SOLBRIG. O. ANII SIMPSON, B. B. 1977. A garden experiment on competition between biotypes of the common dandelion (Taraxacum officinale). J. Ecol., 65, 427-430.

SØRENSEN, Th. 1958. Sexual chromosome-aberants in triploid apomictic 'Taraxaca. Bot. Tidsskr., 54, 1-22.

STERK, A. A., GROENHART, M. C. ANI MOOREN, F. J. A. 1983. Aspects of the ecology of some microspecies of Taraxacum in the Netherlands. Acta Bot. Neerl., 32, 385-415.

STODDART, J. A. 1983. The accumulation of genetic variation in a parthenogenetic snail. Evolution, 37, 546-554.

SUOMALAINEN, E., SAURA. A. AND IOKKI, J. 1976. Evolution of parthenogenetic insects. Evolutionary Biology, 9, 209-257. 